Article

\title{
Impacts of Global Warming on the Radial Growth and Long-Term Intrinsic Water-Use Efficiency (iWUE) of Schrenk Spruce (Picea schrenkiana Fisch. et Mey) in the Sayram Lake Basin, Northwest China
}

\author{
Li Qin ${ }^{1}$, Yujiang Yuan ${ }^{1}$, Huaming Shang ${ }^{1}$, Shulong Yu ${ }^{1}$, Weiping Liu ${ }^{2}$ and Ruibo Zhang ${ }^{1, *}$ \\ 1 Key Laboratory of Tree-ring Ecology of Xinjiang Uigur Autonomous Region, Key Laboratory of Tree-ring \\ Physical and Chemical Research of China Meteorological Administration, Institute of Desert Meteorology, \\ China Meteorological Administration, Urumqi 830002, China; Qinli@idm.cn (L.Q.); Yuanyj@idm.cn (Y.Y.); \\ Shanghm@idm.cn (H.S.); Yusl@idm.cn (S.Y.) \\ 2 Center of Xinjiang Meteorological Information, Urumqi 830002, China; Liuweiping121@126.com \\ * Correspondence: river0511@163.com; Tel.: +86-991-2662971; Fax: +86-991-2621387
}

Received: 17 February 2020; Accepted: 24 March 2020; Published: 27 March 2020

check for updates

\begin{abstract}
Global warming and the sharp rise in atmospheric $\mathrm{CO}_{2}$ concentrations have a profound impact on forest ecosystems. To better manage these changes, a comprehensive understanding of forest ecosystem responses to global change is essential. There is a lack of knowledge about the growth response of Schrenk spruce (Picea schrenkiana Fisch. et Mey) -an endemic tree species found in the arid Central Asian region-to climate change and rising atmospheric $\mathrm{CO}_{2}$ concentrations. In this study, core samples of Schrenk spruce were collected in the Sayram Lake Basin, Xinjiang. Tree-ring radial growth and long-term intrinsic water-use efficiency (iWUE) chronologies were established based on standard tree-ring width and stable carbon isotope methods. The relationships between atmospheric $\mathrm{CO}_{2}$ concentrations, climate, radial growth, and iWUE were analyzed. Our results indicate that the iWUE of trees in this region has continued to rise rapidly but that radial growth has not increased over the past 160 years. The main factor affecting iWUE is atmospheric $\mathrm{CO}_{2}$ concentrations $\left(C_{a}\right)$, whereas the radial growth is much more sensitive to water availability. This may explain why the increase $C_{a}$ has not had a fertilizer effect on the radial growth of trees.
\end{abstract}

Keywords: tree rings; stable carbon isotope; intrinsic water-use efficiency (iWUE); climate change; Schrenk spruce (Picea schrenkiana Fisch. et Mey); Tianshan mountains

\section{Introduction}

Over the past century, the global temperature has increased by $0.85{ }^{\circ} \mathrm{C}\left(0.65-1.06{ }^{\circ} \mathrm{C}\right)$ from 1880 to 2012 [1] and the atmosphere $\mathrm{CO}_{2}$ concentrations $\left(C_{a}\right)$ has increased from $303 \mu \mathrm{mol} / \mathrm{mol}$ to $412 \mu \mathrm{mol} / \mathrm{mol}[2,3]$. Global warming and increased $C_{a}$ have profound effects on forest ecosystems, directly regulate their physiological processes, such as photosynthesis, and indirectly alter forest structure [4]. Meanwhile, forests are the most active carbon sinks in response to the current warming [5]. Theoretically, increasing $C_{a}$ could have a fertilizing effect on trees, leading to an increase in plant growth rates and an (indirect) reduction in transpiration [6-8]. However, the magnitude of the fertilization effect in natural forests is one of the biggest uncertainties in the global carbon cycle [9]. At present, the long-term effects of increasing $C_{a}$ on the growth of trees in natural forests are not fully understood. Studies have shown that $C_{a}$ and intrinsic water-use efficiency (iWUE) have increased more than expected over the past century, causing trees to grow faster [10-13]; others have shown stable or even 
declined tree growth [14-18]. It is thought that trees may adapt to elevated $C_{a}$ and become less sensitive to increases in carbon dioxide [14].

Tree rings provide an opportunity to test the $\mathrm{CO}_{2}$ fertilization hypothesis $[9,16]$. The stable carbon isotope ratio $\left(\delta^{13} \mathrm{C}\right)$ of tree rings can be used to infer iWUE changes [11] and to track the long-term, combined effects of rising $\mathrm{CO}_{2}$ on water use efficiency and tree growth [17]. Tree-ring $\delta^{13} \mathrm{C}$ has been widely used to study iWUE changes and their relationship to tree growth and environmental factors $[10,19]$. Elevated $\mathrm{CO}_{2}$ levels in the atmosphere are expected to improve tree growth rates and iWUE [7]. However, an analysis of tree growth, iWUE, and climate over the past 150 years in the tropical region of southeast China by Li et al. [20] suggests that the radial growth of trees is not significantly affected by water use efficiency. Huang et al. [21] suggest that an increase in iWUE contributes to tree growth, but that temperature controls inter-annual changes in tree growth at the timberline on the southeastern Qinghai-Tibetan Plateau. The fertilizing effects of $\mathrm{CO}_{2}$ have been observed under drought conditions in northwestern China. Huang et al. [14] suggest that increased $C_{a}$ levels can alleviate drought stress for trees. Similarly, Liu et al. [22] show that higher $C_{a}$ levels stimulate the radial growth of trees on the banks of Heihe River, making up for the negative effects of reduced river flow and an arid climate.

The Tianshan Mountains are located in the inland region of western China at the center of Eurasia. Their total length is $2500 \mathrm{~km}$ and they span about one million square kilometers. There are a large number of Schrenk spruce (Picea schrenkiana Fisch. et Mey) virgin forests in this region and this species has been shown to be suitable for dendrochronological study [23-38]. However, few studies have discussed the relationship between $C_{a}$, climate, radial growth, and iWUE in the Tianshan Mountains $[39,40]$. Sayram Lake is located in this arid region, and its climate is affected by the westerlies. Many Schrenk spruce forests are distributed on the shady slopes of the sub-alpine belt in the mountains around Sayram Lake. In this study, tree-ring width and $\delta^{13} \mathrm{C}$ chronologies were established for the Sayram Lake Basin, and the relationships between $C_{a}$, climate, radial growth, and iWUE were analyzed. Using this information, we explore the effects of global change on the radial growth and water use efficiency of Schrenk spruce.

\section{Data and Methods}

\subsection{Study Area and Tree-Ring Sampling Site}

The study area is located in the Sayram Lake Basin in western Tianshan, China $\left(80^{\circ} 59^{\prime}-81^{\circ} 22^{\prime} \mathrm{E}\right.$, $44^{\circ} 29^{\prime}-44^{\circ} 32^{\prime} \mathrm{N}$ ). The catchment area of the lake is $1408 \mathrm{~km}^{2}$, and there are 39 small rivers in the lake area. Sayram Lake is fed primarily by precipitation that falls in the surrounding mountains. Water vapor brought by the westerly circulation is the main source of moisture for the area. Schrenk spruce covers the shady slopes of the sub-alpine zone $(2150-2600 \mathrm{~m}$ ) around the lake, forming a dark, primitive coniferous forest. Schrenk spruce forest is the most dominant and widespread boreal forest type in the Tianshan Mountains. It is also one of the most important zonal vegetation types in the region.

Tree-ring samples were collected in 2010 at Haixigou, which is located in the northern part of the Sayram Lake Basin ( $81^{\circ} 11^{\prime}$ E, $44^{\circ} 43^{\prime}$ N; designated "HXG" group; elevation is $2240-2280 \mathrm{~m}$ a.s.l.) (Figure 1). To minimize non-climatic effects, we identified representative trees with minimal bole and crown damage for sampling. Two cores were extracted at breast height from each tree at cross-slope positions using a 10-mm diameter Swedish increment borer. Trees grow on the north or northwest slopes of the study area, typically on slopes of 20-40 degrees. In total, 60 increment cores were collected from 30 healthy trees. 


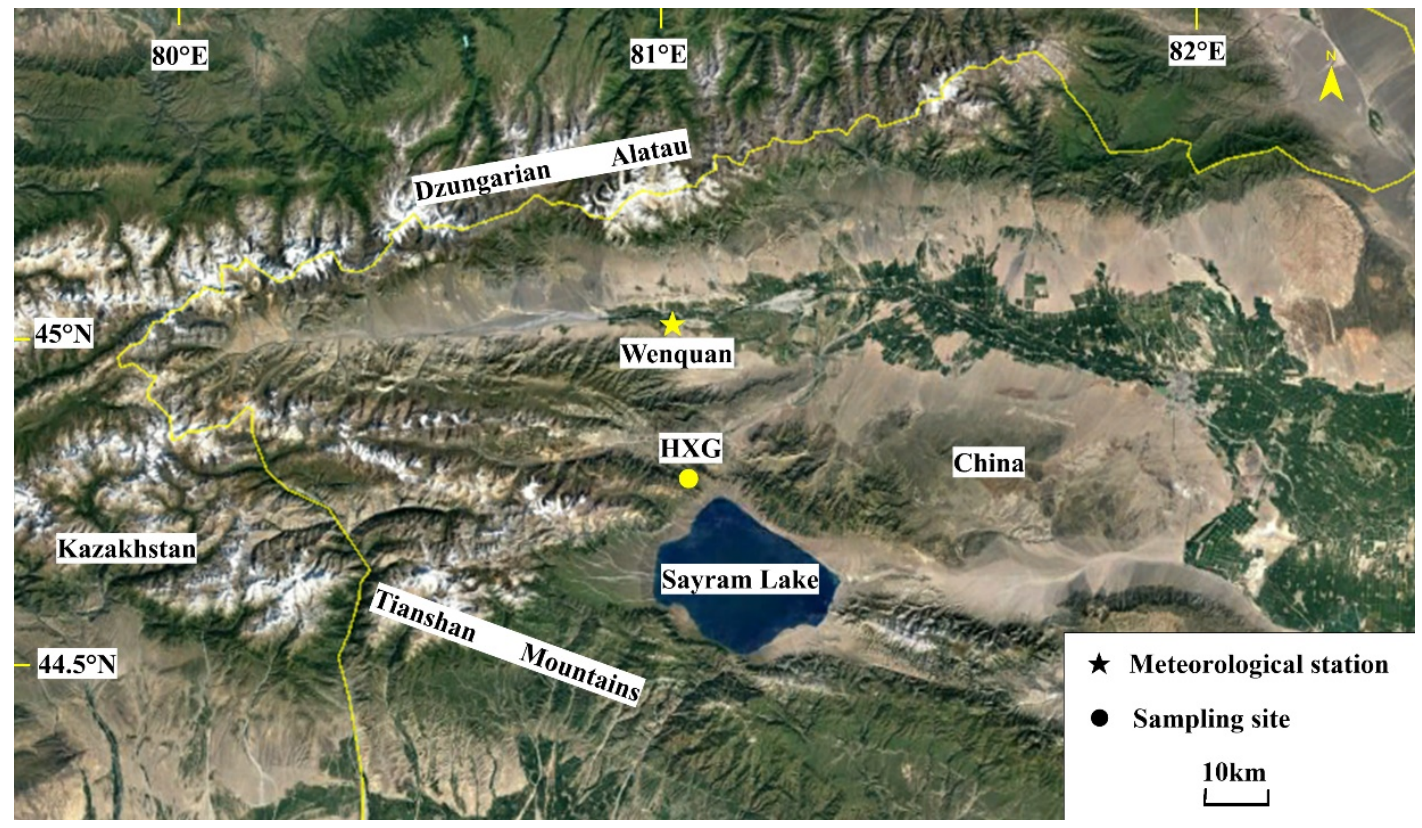

Figure 1. Map of tree-ring sample site and meteorological station information.

\subsection{Establishing the Tree-Ring-Width Chronology}

All tree-ring samples were dried naturally, mounted, and sanded until the ring structures were clear following standard dendrochronological methods. A preliminary dating of the cores was done under a binocular microscope, and rings were measured with $0.001 \mathrm{~mm}$ precision using a Velmex measuring system [41]. All cores were cross-dated with comparison samples, TT, and the COFECHA program [42] to ensure exact dating for each annual ring. The program ARSTAN [43] was used to develop the tree-ring width chronology. Finally, we established a standard (STD) chronology using the spline curve method (step length of 110) (Figure 2) in order to de-trend the natural trend of radial tree growth [44].

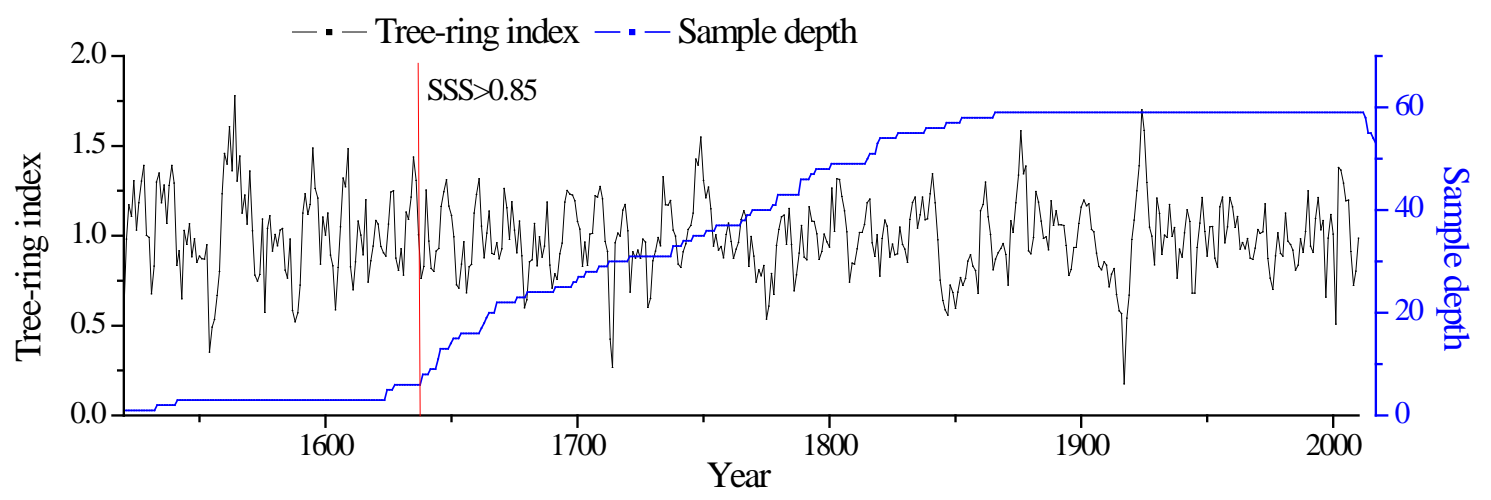

Figure 2. Tree-ring width chronology (STD) for the Haixigou sampling site detrended by spline function.

\subsection{Stable Carbon Isotopic Extraction}

For stable carbon isotope analysis, we selected 10 cores from five trees without missing rings or growth abnormalities that are highly correlated with the main sequence. We used a scalpel to separate each annual ring under a binocular microscope, then mixed the woody material from all samples in a given year to produce a single composite sample. The chronology covers the period from 1850 to 2008; there was too little radial growth of trees in 2009 and 2010 for cellulose extraction. All pooled samples were grounded into powder in a ball mill (MM 400, Retsch $\mathrm{GmbH}$, Germany), and the $\alpha$ 
cellulose was extracted using the method of Brendel et al. [45]. This method has been widely used in dendroclimatology studies $[34,35,46]$.

The $\alpha$ cellulose $\delta^{13} \mathrm{C}$ values of the tree-ring were measured using a stable isotope ratio mass spectrometer (MAT253, Thermo Fisher Scientific Bremen GmbH, Germany) coupled with an element analyzer (Flash EA 1112; Thermo Fisher Scientific, Waltham, MA, USA).

We measured the laboratory standard after every seven samples in order to calibrate the error of the instruments. The Glycine, Graphite, and Soil standards were used interchangeably. The analytical errors (standard deviations) of all the isotope standards were less than $0.056 \%$. $\delta^{13} \mathrm{C}$ was expressed relative to the Vienna Pee Dee Belemnite (VPDB) standard [47,48]:

$$
\delta^{13} C=\left[\frac{\left({ }^{13} C /{ }^{12} C\right)_{\text {sample }}}{\left({ }^{13} C /{ }^{12} C\right)_{V P D B}}-1\right] \times 10^{3} \% \text { o }
$$

From this, a tree-ring $\delta^{13} \mathrm{C}$ chronology from 1850 to 2008 was obtained.

\subsection{Long-Term Intrinsic Water-Use Efficiency (iWUE) Calculations}

The majority of trees has $C_{3}$ photosynthesis and thus is more directly dependent on variations of the $\mathrm{CO}_{2}$ atmospheric concentration [2]. The carbon isotope discrimination $\left(\Delta^{13} \mathrm{C}\right)$ in $\mathrm{C}_{3}$ plants can be expressed as:

$$
\Delta^{13} C=\frac{\delta^{13} C_{a}-\delta^{13} C_{p}}{1+\delta^{13} C_{p} / 1000}
$$

where $\delta^{13} C_{a}$ and $\delta^{13} C_{p}$ represent the stable carbon isotopic values of ambient air and plant cellulose, respectively [49]. Discrimination against ${ }^{13} \mathrm{C}$ during carbon fixation by trees (and other C3 plants) can be expressed as

$$
\Delta^{13} C=a+(b-a) \times\left(C_{i} / C_{a}\right)
$$

where $a\left(\approx 4.4 \%\right.$ o) is the discrimination against ${ }^{13} \mathrm{CO}_{2}$ during diffusion through the stomata, $b(\approx 27 \%$ o) is the net discrimination due to carboxylation and $C_{i}$ and $C_{a}$ are the $\mathrm{CO}_{2}$ concentrations in the intercellular space of leaves and in the atmosphere, respectively [2].

The ratio of the $\mathrm{CO}_{2}$ assimilation rate (A) to stomatal conductance $\left(\mathrm{g}_{\mathrm{s}}\right)$ for water vapor is defined as the intrinsic water-use efficiency (iWUE), which is calculated as

$$
i W U E=A / g_{s}=C_{a} \times\left[\left(1-C_{i} / C_{a}\right) / 1.6\right]
$$

where $A\left(\mathrm{~mol} \cdot \mathrm{m}^{-2} \mathrm{~s}^{-1}\right)$ is the rate of $\mathrm{CO}_{2}$ assimilation by the tree's leaves, $g_{\mathrm{s}}\left(\mu \mathrm{mol} \cdot \mathrm{m}^{-2} \mathrm{~s}^{-1}\right)$ is the rate of leaf stomatal conductance, $C_{a}$ is the ambient $\mathrm{CO}_{2}$ concentration, and $C_{i}$ is the intercellular leaf $\mathrm{CO}_{2}$ concentration [50,51].

\subsection{Climate Data}

We obtained climatological information from the Wenquan meteorological station $\left(44^{\circ} 58^{\prime} \mathrm{N}\right.$, $81^{\circ} 01^{\prime}$ E, elevation $1353.9 \mathrm{~m}$ ) for the period 1959-2010 (China Meteorological Science Data Center, https://data.cma.cn). This is the closest station to the sampling site, with a straight line distance of less than $30 \mathrm{~km}$. Analysis of monthly changes in observation data from the Wenquan meteorological station reveals that both average monthly temperature and precipitation are unimodal in the study area, and that peaking occurs in July (Figure 3a). This means that the region has a typical continental climate. The average annual precipitation in the study area is $231.8 \mathrm{~mm}$, and the mean temperature is $3.93{ }^{\circ} \mathrm{C}$. Both mean temperature and precipitation have increased significantly over the past 52 years, with amplitudes of $0.24{ }^{\circ} \mathrm{C} /$ decade and $15.6 \mathrm{~mm} /$ decade, respectively. The warming and wetting process has been most obvious since the 1980s (Figure 3b). These changes are in line with the warming 
and wetting trend observed in areas with similar climatic conditions in arid northwest China [52]. The monthly vapor pressure deficit (VPD) is calculated using the following equation:

$$
\mathrm{VPD}=(1-\mathrm{RH}) \times 0.6108 \times \mathrm{e}^{(17.27 \mathrm{~T} /(\mathrm{T}+273.3))}
$$

where VPD is monthly mean vapor pressure deficit, $\mathrm{RH}$ is the monthly mean relative humidity, and T is the monthly mean temperature [53].
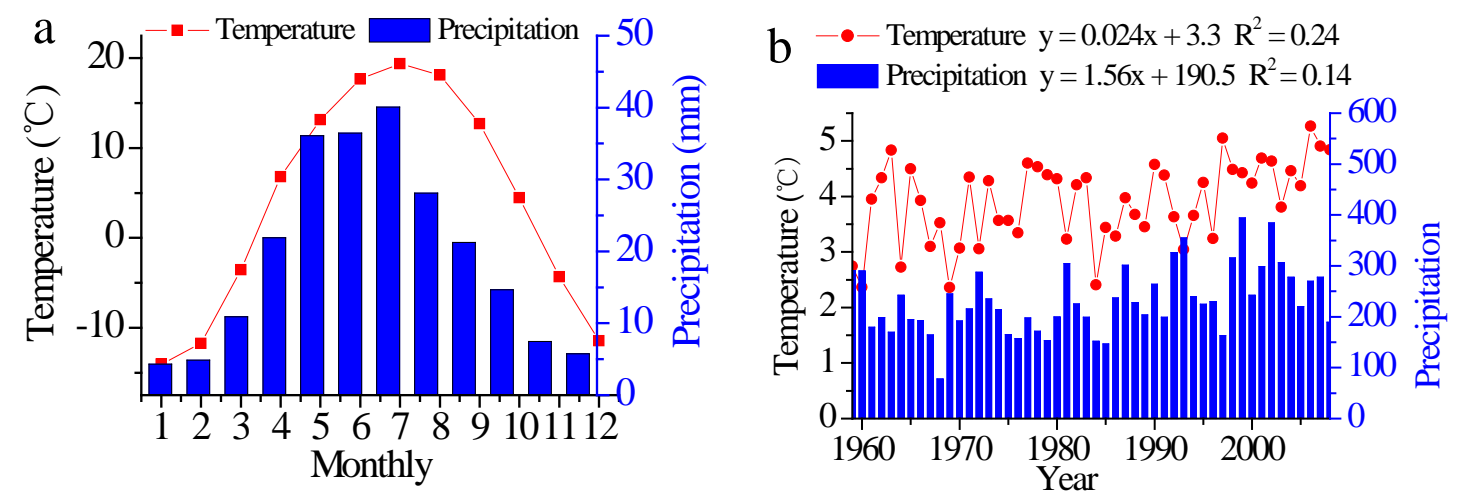

Figure 3. Monthly (a) and annual (b) changes in mean temperature and total precipitation at the Wenquan meteorological station (1959-2010).

The self-calibrated Palmer Drought Severity Index (scPDSI) was obtained from the gridded datasets of the Climate Research Unit (CRU) TS 3.22 (Harris et al., 2014) for the period 1901-2014 using the KNMI Climate Explorer (http://climexp.knmi.nl/start.cgi). We chose the monthly scPDSI of the CRU grid $\left(81^{\circ} 20^{\prime} \mathrm{E}, 44^{\circ} 40^{\prime} \mathrm{N}\right)$ nearest the sampling site for further analysis. We also used the standardized precipitation-evapotranspiration index (SPEI) data (1901-2015) of the nearest grid $\left(81^{\circ} 20^{\prime} \mathrm{E}, 44^{\circ} 40^{\prime} \mathrm{N}\right)$. The data were obtained from the global SPEI database, with a 0.5-degree spatial resolution (http://sac.csic.es/spei/database.html).

\subsection{Statistical Methodology}

We used conventional mathematical statistical methods to analyze the data [41]. Climate-growth response analyses were performed over the length of a biological year (i.e., previous October to current September) because tree growth can be affected by the climatic conditions of both the previous and current growing seasons. The relationships between climatic factors and tree-ring parameters were analyzed using Pearson correlation analysis with the Statistical Product and Service Solutions (SPSS Statistics 21) program.

\section{Results and Discussion}

\subsection{Changes in Tree-Ring $\delta^{13} \mathrm{C}$ and iWUE}

For the period 1850 to 2008 , Schrenk spruce tree-ring $\delta^{13} \mathrm{C}$ values ranged from $-24.68 \%$ o to $-20.95 \%$, with an average value of $-22.62 \%$ (Table 1 ). Over the past 158 years, $\delta^{13} \mathrm{C}$ in tree rings exhibits a decreasing trend, with an average annual decline of $0.011 \%$. Prior to the 1970 s, the decline in $\delta^{13} \mathrm{C}$ was slow, with a slope of $0.005 \%$. Starting in the 1980 s, the decline became steeper, with a slope of $0.035 \%$. The $\delta^{13} \mathrm{C}$ value of plant tissues is significantly lower than that of the atmosphere. In $\mathrm{C}_{3}$ plants, it is generally between $-20 \%$ and $-35 \%$, with the majority of $C_{3}$ plants having values between $-25 \%$ o and $-28 \%$ o. In arid regions, the $\delta^{13} \mathrm{C}$ value of $\mathrm{C}_{3}$ plants is relatively higher. The $\delta^{13} \mathrm{C}$ values obtained in this study $\left(-24.68 \%\right.$ o to $-20.95 \%$ ) are within the expected range for $C_{3}$ plants (Table 1 , Figure 4). 
Table 1. The statistical characteristics of tree-ring $\delta^{13} \mathrm{C}$ and iWUE (1850-2008).

\begin{tabular}{cccccccc}
\hline & Maximum & Minimum & Mean & $\begin{array}{c}\text { Standard } \\
\text { Deviation }\end{array}$ & Variance & Skewness & Kurtosis \\
\hline$\delta^{13} \mathrm{C}(\% \mathrm{o})$ & -20.95 & $-24.68 \%$ & $-22.62 \%$ & 0.717 & 0.514 & -0.616 & 0.256 \\
\hline $\mathrm{iWUE}(\mu \mathrm{mol} / \mathrm{mol})$ & 120.93 & 79.78 & 94.73 & 7.98 & 63.736 & 0.849 & 0.457 \\
\hline
\end{tabular}

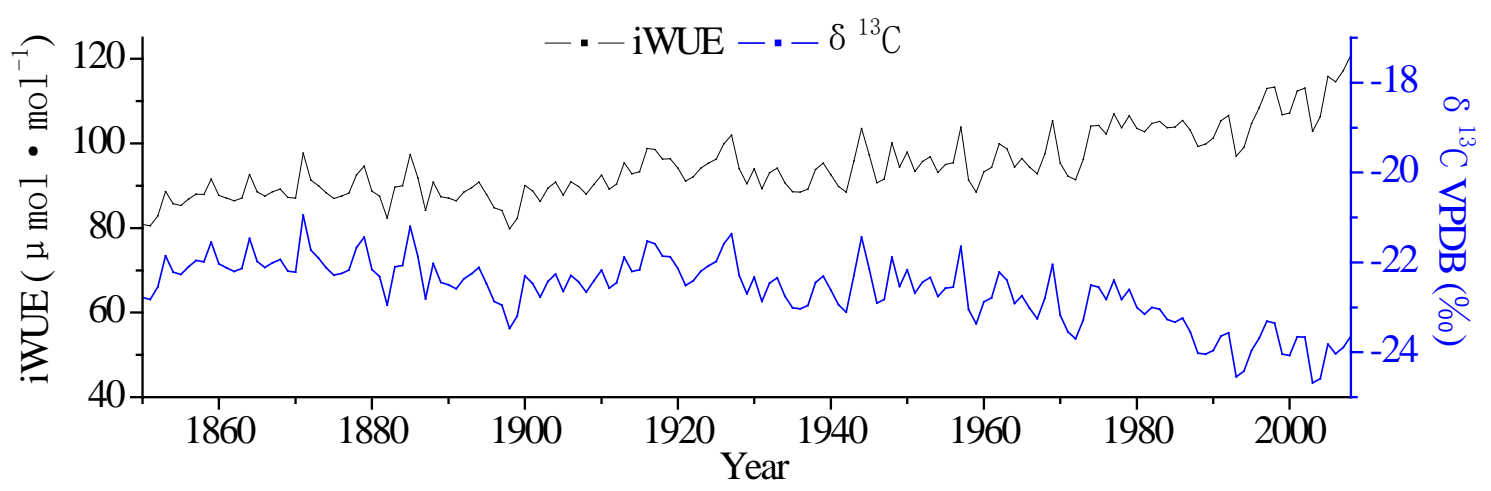

Figure 4. The $\delta^{13} \mathrm{C}$ and Intrinsic water-use efficiency (iWUE) chronologies from 1850-2008 for the Sayram Lake Basin.

The iWUE of Schrenk spruce in the Sayram Lake Basin increased significantly and non-linearly from 1850 to 2008 and is negatively correlated with tree ring $\delta^{13} \mathrm{C}$. The iWUE of trees in this region ranges from 79.78 to $120.93 \mu \mathrm{mol} \mathrm{mol}{ }^{-1}$ and exhibits an average annual increase of $0.141 \mu \mathrm{mol} \cdot \mathrm{mol}^{-1}$ (Table 1). The maximum iWUE value occurred in 2008; the minimum occurred in 1898 (Figure 4). Prior to the 1980s, iWUE increased slowly, with an average value of $91.35 \mu \mathrm{mol} \cdot \mathrm{mol}^{-1}$ and a rate of increase of $0.09 \mu \mathrm{mol} \cdot \mathrm{mol}^{-1}$. Accompanied by the warming and humidification process in Xinjiang after the 1980s, the iWUE increased rapidly, with an average value of $105.15 \mu \mathrm{mol} \cdot \mathrm{mol}^{-1}$ and a rate of increase of $0.416 \mu \mathrm{mol} \mathrm{mol}{ }^{-1}$.

\subsection{Response of Tree Radial Growth and iWUE to Environmental Factors}

Pearson correlation analysis shows that there is no significant correlation between radial growth and increasing atmospheric $\mathrm{CO}_{2}$ concentration. Radial growth is significantly negatively correlated with May-July temperature and VPD, and its correlation coefficient with VPD in May is as high as -0.448 ( $p<0.01, n=51$; Figure 5). At the same time, the radial growth of trees is significantly and positively correlated with precipitation, relative humidity, SPEI, and ScPDSI in the growing season (Figure 5). Whether radial growth is negatively related to temperature and VPD or positively related to relative humidity and precipitation, these results indicate that the main environmental factor affecting the radial growth of trees is water stress, especially during the growing season. Many other studies have confirmed that the radial growth of Schrenk spruce is limited by water stress during the main growing season [26-35]. Yuan et al. [26] found that tree-ring width chronologies are most closely correlated with the number of precipitation days between 20 May and 8 June in the Urumqi River Basin. Zhang et al. [54] analyzed intra-annual radial growth of Schrenk spruce based on data from continuously monitored dendrometers and found that radial growth is positively correlated with precipitation and relative humidity $(\mathrm{RH})$, and negatively correlated with evaporation and vapor pressure deficit (VPD). The authors suggest that tree growth on the northern slopes of the Tianshan Mountains is moisture-limited. Our results are consistent with the results from the continuously monitored dendrometers. The increasing trend in VPD magnifies evaporation and plant transpiration [55]. The combination of elevated temperatures and VPD may therefore lead to more severe droughts and may have a fundamental impact on plant and forest ecosystems [56]. 


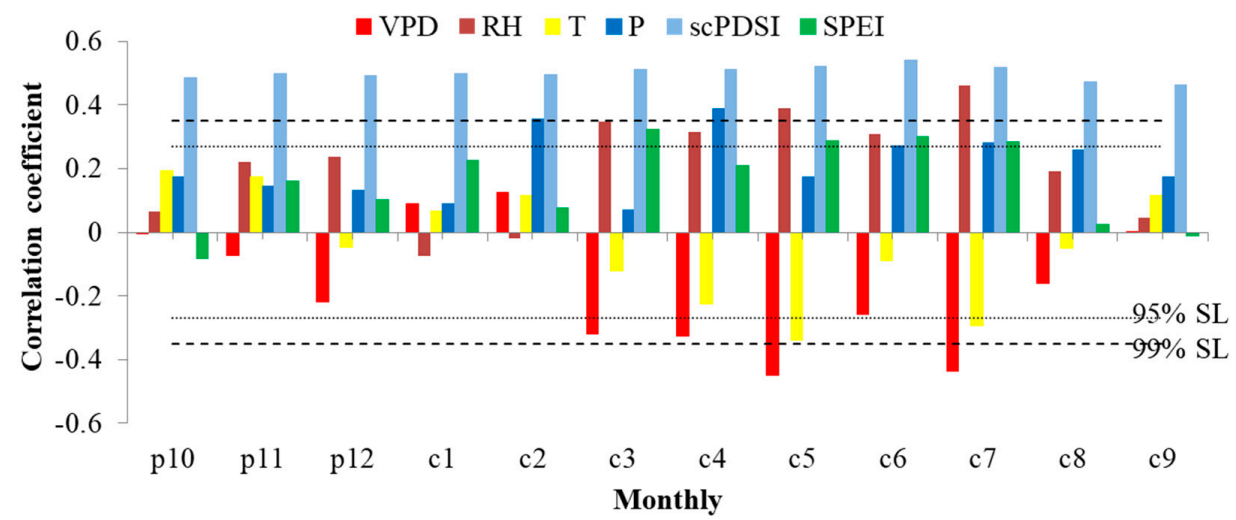

Figure 5. Correlation coefficients of tree radial growth with main meteorological factors (1960-2010). VPD, RH, T, P, scPDSI, and SPEI represent vapor pressure deficit, relative humidity, mean temperature, precipitation, self-calibrated Palmer drought severity index, and standardized precipitationevapotranspiration index, respectively.

The correlation coefficient between iWUE and atmospheric $\mathrm{CO}_{2}$ concentration $\left(C_{a}\right)$ is as high as $0.803(n=50, p<0.01)$ (Figure 6). Meanwhile, iWUE correlates significantly with temperature and VPD, with correlation coefficients of $0.554(p<0.01, n=50)$ and $0.427(p<0.01, n=50)$, respectively (Figure 6). However, there is no significant correlation between iWUE and precipitation changes (Figure 6). This suggests that changes in iWUE may be related to photosynthesis and transpiration. The high correlation between iWUE and atmospheric $\mathrm{CO}_{2}$ concentration $\left(C_{a}\right)$ may be due to increased $C_{a}$, which can increase the photosynthesis rate and reduce stomatal conductance, leading to improved iWUE $[14,39,49]$. Numerous studies have attributed the increase in plant iWUE to the continued increase in $C_{a}[6,16,51]$.
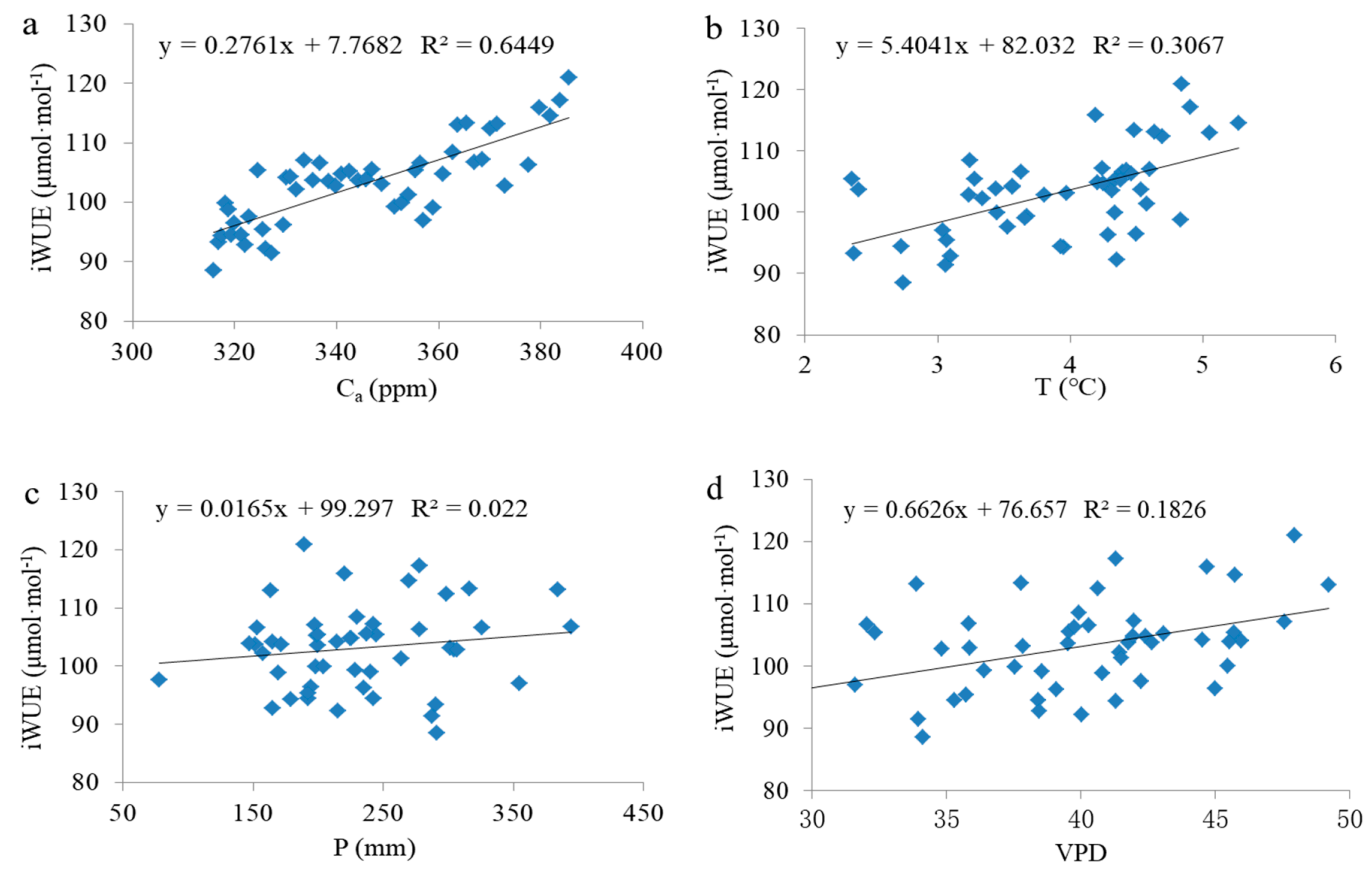

Figure 6. Correlation analysis between the iWUE and main environmental factors (1959-2008). (a) the correlation between the iWUE and atmospheric $\mathrm{CO}_{2}$ concentration $\left(C_{a}\right)$; (b) the correlation between the iWUE and mean temperature (T); (c) the correlation between the iWUE and annual total precipitation $(\mathrm{P}) ;(\mathbf{d})$ the correlation between the iWUE and vapor pressure deficit (VPD). 
In this study, we find that intercellular $\mathrm{CO}_{2}$ concentration $\left(C_{i}\right)$ increases with increasing $C_{a}$ and that trees are not showing any signs of adaptations that would allow them to maintain constant $C_{i}$ (Figure 7a). However, the $C_{i} / C_{a}$ ratio has barely changed over the past 160 years (Figure $7 \mathrm{~b}$ ). This ratio reflects the balance between the net assimilation of $\mathrm{CO}_{2}(\mathrm{~A})$ and stomatal conductance $\left(\mathrm{g}_{\mathrm{s}}\right)$ according to Fick's law: $\mathrm{A}=\mathrm{g}_{\mathrm{s}}\left(C_{a}-C_{i}\right)$. The stability of the $C_{i} / C_{a}$ ratio indicates that changes in $C_{i}$ and $C_{a}$ are consistent in both timing and magnitude, and that there is no physiological response to higher $C_{a}$ levels. Previous studies have also found that $C_{i} / C_{a}$ has remained constant over the past century $[10,57,58]$. The constant $C_{i} / C_{a}$ ratio means that $C_{i}$ increases synchronously with increasing $C_{a}$. According to the theory of Saurer et al. [10], this is an active response of the iWUE to the increasing $C_{a}$ (Figure $7 \mathrm{c}$ ). Similar results have been revealed by many previous studies [21,52,59]. Before the 1980s, the trend in iWUE strongly reflected the trend that would exist under a scenario of constant $C_{i}$ (which assumes a strong response to $C_{a}$ ). However, iWUE values after the 1980s are more consistent with the values predicted under a scenario with constant $C_{i} / C_{a}$. This phenomenon may be related to changes in physiological mechanisms caused by the rapid warming that began in the 1980 s.
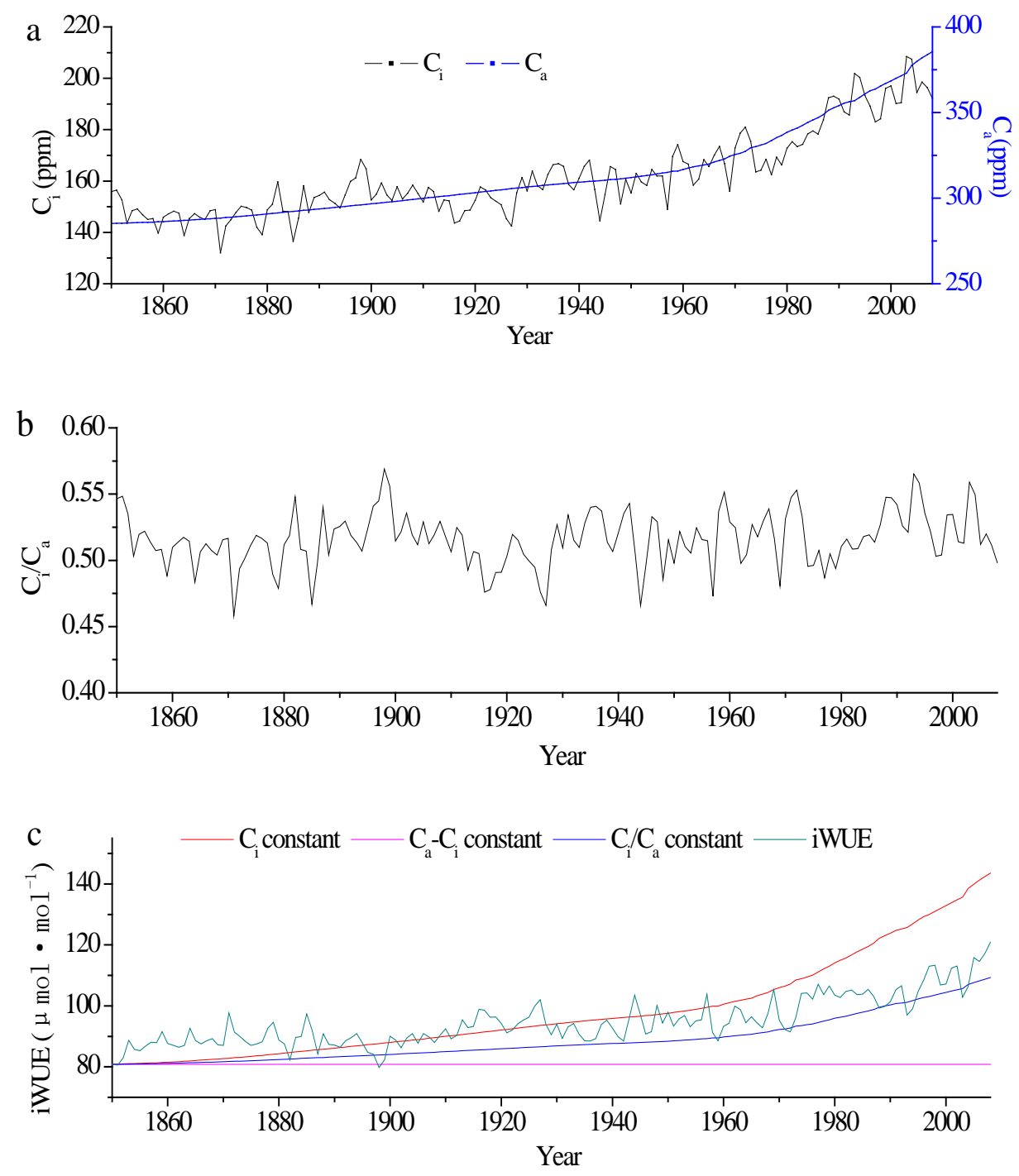

Figure 7. (a) Change in the leaf intercellular $\mathrm{CO}_{2}$ concentration $\left(C_{i}\right)$ and ambient $\mathrm{CO}_{2}$ concentration; (b) ${ }^{13} \mathrm{C}$ discrimination ratios $\left(C_{i} / C_{a}\right)$; (c) intrinsic water-use efficiency (iWUE) calculated from three scenarios as a baseline for interpreting gas exchange in response to increasing $C_{a}$ over the past 160 years. 
Collinearity analysis shows that atmospheric $\mathrm{CO}_{2}$ concentration $\left(C_{a}\right)$, temperature $(\mathrm{T})$, and vapor pressure deficit (VPD) can explain $87.1 \%$ of the variance in iWUE. $C_{a}$ explains the largest portion (64.5\%) of iWUE changes based on a commonality analysis for the period for which there are meteorological observation data (Figure 8). The factors affecting the radial growth of trees are more complicated. The contribution of the three environmental factors to the radial growth of trees is $63.2 \%$. VPD has the strongest influence, whereas $C_{a}$ promotes radial growth mainly by affecting tree physiological processes. If this physiological effect is not considered, the three environmental factors only explain $46.4 \%$ of the variance in the radial growth of trees, and $C_{a}$ appears to have almost no direct influence. Hence, the main factor driving iWUE is $C_{a}$, whereas the main factor limiting the radial growth of trees is water stress (VPD). The VPD has not increased in the past few decades, so the radial growth of trees has not shown a significant increase. This may be the reason why the increase in $C_{a}$ has not resulted in a fertilizer effect on tree radial growth. Giguere-Croteau et al. [60] have also shown that trees have not benefitted from increased iWUE due to increased $C_{a}$ since 1850.

\section{a. iWUE}

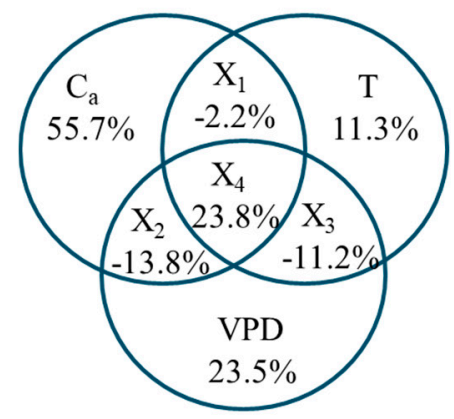

Total: $87.1 \%$ b. RAW

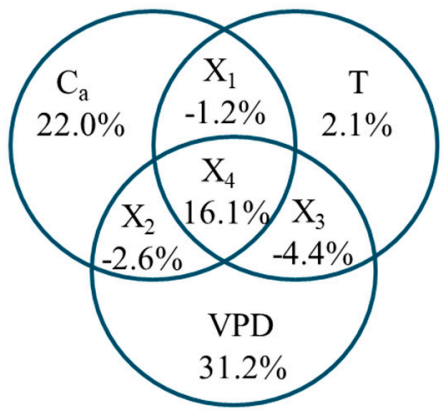

Total: $63.2 \%$ c. STD

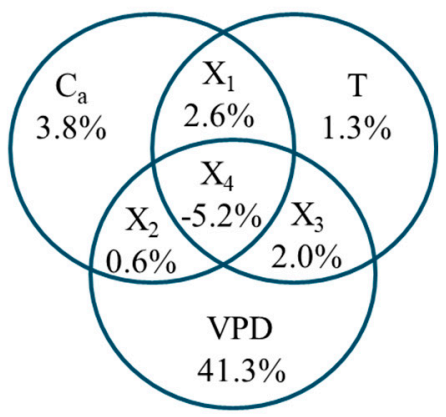

Total: $46.4 \%$

Figure 8. Radial growth and changes in iWUE as explained by the commonality analysis. The analysis combinations are as follows: pure effect of atmosphere $\mathrm{CO}_{2}$ concentration $\left(C_{a}\right)$, pure effect of temperature $(\mathrm{T})$, pure effect of vapor pressure deficit (VPD), comprehensive impact by atmosphere $\mathrm{CO}_{2}$ concentration and temperature $\left(\mathrm{X}_{1}\right)$, comprehensive impact by atmosphere $\mathrm{CO}_{2}$ concentration and VPD $\left(\mathrm{X}_{2}\right)$, comprehensive impact by temperature and VPD $\left(\mathrm{X}_{3}\right)$, and comprehensive impact by all predictors $\left(\mathrm{X}_{4}\right)$. The corresponding percentage values represent the explained variance of each fraction. RAW represents the original tree-ring width chronology; STD represents the de-trended width chronology using the spline function method.

Further analysis reveals that $C_{a}$ explains the majority of iWUE changes during the period for which there are meteorological observations; climate change explains the others (Figure 8). The increase in $C_{a}$ is expected to affect the relationship between plant carbon and water utilization by reducing stomatal conductance [61,62]. However, although higher $C_{a}$ concentrations cannot directly promote tree radial growth, they may promote tree growth by increasing the photosynthetic rate. This then reduces the stomatal conductance for the physiological adaptability of trees to the increasing $C_{a}$ [63]. Meanwhile, a warming environment enhances plant evapo-transpiration and soil transpiration, which further reduces stomatal conductance.

The leaf stomata of Schrenk spruce in the Sayram Lake Basin reduce or close their aperture in response to increasing global atmospheric $\mathrm{CO}_{2}$ concentrations. This reduces the rate of photosynthesis and enhances the water use efficiency. Increasing temperatures cause a decrease in soil moisture, which results in drought stress, which further reduces the radial growth of trees [6,51]. This pattern of differentiation between iWUE and tree growth is considered evidence of water stress caused by warming $[16,17,51]$. In summary, climatic factors, especially changes in water stress, are the main factors affecting the growth of Schrenk spruce in the Sayram Lake Basin. 


\subsection{The Relationship between Radial Growth and iWUE}

The iWUE exhibits a clear increasing trend, but radial growth of Schrenk spruce growing in the Sayram Lake Basin hasn't increased over the past 160 years (Figure 2). An analysis of the relationship between iWUE and radial growth shows that the correlation coefficient is as high as $-0.711(p<0.01$, $n=50$ ). The sliding correlation indicates that there is significant correlation during the 1910 s and over the last 51 years, but the correlation is not significant during other periods. The correlation has been weakening since the late 1980s, in synch with increasing precipitation. Thus, when the climate is generally dry, iWUE is more strongly correlated with the radial growth of trees. The correlation weaken as precipitation increases. However, the first-order difference correlation analysis shows that there is no significant correlation between iWUE and radial growth in high-frequency changes, a finding that is corroborated by the first-order difference sliding correlation (Figure 9). There is therefore no direct relationship between iWUE and radial growth with respect to long-term changes.

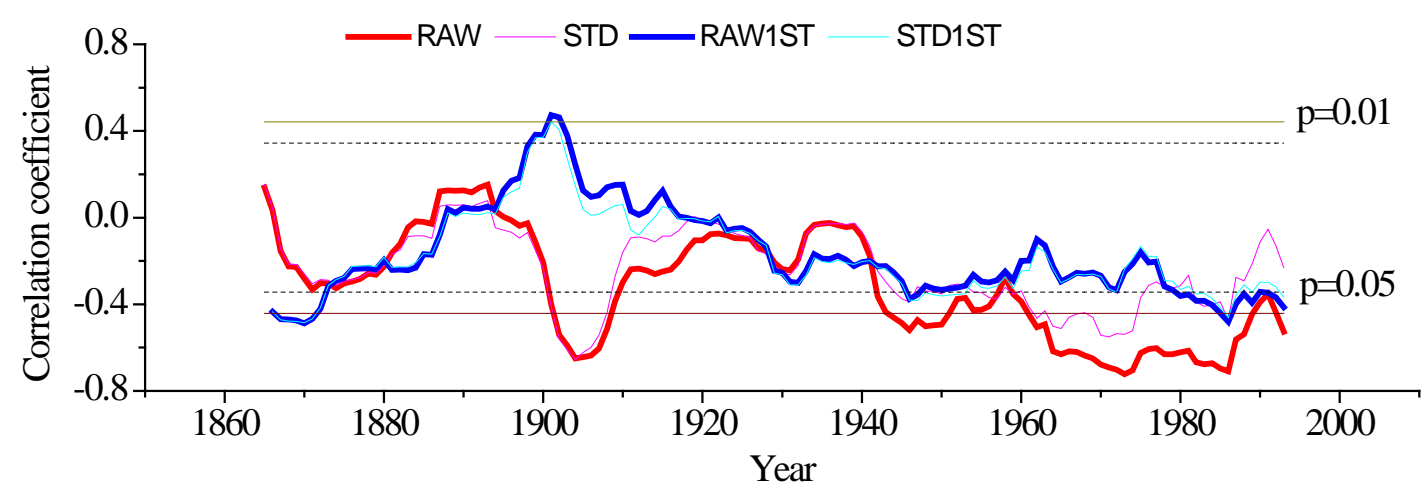

Figure 9. The 30-year sliding correlation between iWUE and the radial growth of trees. RAW represents the correlation coefficient between the iWUE and the original tree-ring width chronology; STD represents the correlation coefficient between the iWUE and the de-trended width chronology using the spline function method; RAW1ST represents the correlation coefficient between the first-order difference of the iWUE and the first-order difference of the original tree-ring width chronology; STD1ST represents the correlation coefficient between the first-order difference of the iWUE and the first-order difference of the de-trended width chronology.

\section{Conclusions}

In this study, we established tree-ring width and iWUE chronologies in order to explore the effects of rising atmospheric $\mathrm{CO}_{2}$ concentrations $\left(C_{a}\right)$ and global warming on the radial growth and iWUE of Schrenk spruce growing in the Sayram Lake Basin. This study shows that while iWUE has continued to rise rapidly and radial growth has not increased over the past 160 years. Radial growth in this region is mainly limited by moisture conditions from May to July. The iWUE has increased significantly since the $1850 \mathrm{~s}$ in response to increasing $C_{a}$ and decreasing stomatal conductance. Stomatal closure is further enhanced by warming-induced drought and is responsible for a sharp increase in iWUE since the 1980s. However, the increased iWUE has not been able to compensate for the negative effects of warming-induced water stress. Hence, the main factor affecting iWUE is atmospheric $\mathrm{CO}_{2}$ concentration $\left(C_{a}\right)$, whereas radial growth is more sensitive to water availability. Although increasing $C_{a}$ is driving a rapid increase in iWUE, it is not having a fertilizer effect on the radial growth of Schrenk spruce in the Sayram Lake Basin. It is expected that the radial growth of Schrenk spruce will decrease further, perhaps even leading to tree mortality as global warming intensifies. This study is helpful for understanding long-term dynamic changes in forest ecosystems in response to global changes and provides a reference for forest resource management in arid regions. 
Author Contributions: Conceptualization, R.Z.; Data curation, L.Q., W.L., and R.Z.; Formal analysis, L.Q.; Funding acquisition, R.Z.; Investigation, Y.Y., R.Z., S.Y., and H.S.; Methodology, L.Q.; Resources, Y.Y.; Validation, L.Q.; Writing—original draft, L.Q. and R.Z.; Writing—review and editing, L.Q. and R.Z. All authors have read and agreed to the published version of the manuscript.

Funding: This study was supported by Key Laboratory Opening Foundation of Xinjiang Uigur Autonomous Region (2019D04002), Natural Science Foundation of Xinjiang Uygur Autonomous Region (2018D01A40), National Natural Science Foundation of China Projects (41975110, 41675152) and China Postdoctoral Science Foundation (2019M650806).

Conflicts of Interest: The authors declare that they have no conflict of interest.

\section{References}

1. IPCC. Climate Change 2013: The Physical Science Basis [M/OL]; Cambridge University Press: Cambridge, UK, 2013. Available online: http://www.ipcc.ch/report/ar5/wg1/\#.Uq_tD7KBRR1.2013 (accessed on 5 January 2019).

2. McCarroll, D.; Loader, N.J. Stable isotopes in tree rings. Quat. Sci. Rev. 2004, 23, 771-801. [CrossRef]

3. Dlugokenky, E.; Tans, P. Trends in Atmospheric Carbon Dioxide; National Oceanic \& Atmospheric Administration: Boulder, CO, USA, 2019. Available online: http://www.esrl.noaa.gov/gmd/ccgg/trends/global.html (accessed on 1 December 2019).

4. Hughes, L. Biological consequences of global warming: Is the signal already apparent? Trends Ecol. Evol. 2000, 15, 56-61. [CrossRef]

5. Barber, V.A.; Juday, G.P.; Finney, B.P. Reduced growth of Alaskan white spruce in the twentieth century from temperature-induced drought stress. Nature 2000, 405, 668-673. [CrossRef] [PubMed]

6. Andreu-Hayles, L.; Planells, O.; Gutierrez, E.; Muntan, E.; Helle, G.; Anchukaitis, K.J.; Schleser, G.H. Long tree-ring chronologies reveal 20th century increases in water-use efficiency but no enhancement of tree growth at five Iberian pine forests. Glob. Chang. Biol. 2011, 17, 2095-2112. [CrossRef]

7. Wang, Y.; Zhang, Y.; Fang, O.; Shao, X. Long-term changes in the tree radial growth and intrinsic water-use efficiency of Chuanxi spruce (Picea likiangensis var. balfouriana) in southwestern China. J. Geogr. Sci. 2018, 28, 833-844. [CrossRef]

8. Morgan, J.; Pataki, D.; Körner, C.; Clark, H.; Del Grosso, S.; Grúnzweig, J.; Knapp, A.; Mosier, A.; Newton, P.; Niklaus, P. Water relations in grassland and desert ecosystems exposed to elevated atmospheric $\mathrm{CO}_{2}$. Oecologia 2004, 140, 11-25. [CrossRef] [PubMed]

9. Babst, F.; Alexander, M.R.; Szejner, P.; Bouriaud, O.; Klesse, S.; Roden, J.; Ciais, P.; Poulter, B.; Frank, D.; Moore, D.J.; et al. A tree-ring perspective on the terrestrial carbon cycle. Oecologia 2014, 176, 307-322. [CrossRef]

10. Saurer, M.; Siegwolf, R.T.W.; Schweingruber, F.H. Carbon isotope discrimination indicates improving wateruse efficiency of trees in northern Eurasia over the last 100 years. Glob. Chang. Biol. 2004, 10, 2109-2120. [CrossRef]

11. Waterhouse, J.S.; Switsur, V.R.; Barker, A.C.; Carter, A.H.C.; Hemming, D.L.; Loader, N.J.; Robertson, I. Northern European trees show a progressively diminishing response to increasing atmospheric carbon dioxide concentrations. Quat. Sci. Rev. 2004, 23, 803-810. [CrossRef]

12. Liu, X.; Shao, X.; Liang, E.; Zhao, L.; Chen, T.; Qin, D.; Ren, J. Speciesdependent responses of juniper and spruce to increasing $\mathrm{CO}_{2}$ concentration and to climate in semi-arid and arid areas of northwestern China. Plant Ecol. 2007, 193, 195-209. [CrossRef]

13. Liu, X.; Shao, X.; Wang, L.; Liang, E.; Qin, D.; Ren, J. Response and dendroclimatic implications of $\delta 13 C$ in tree rings to increasing drought on the northeastern Tibetan Plateau. J. Geophys. Res. Atmos. 2008, 113, G03015. [CrossRef]

14. Huang, J.; Bergeron, Y.; Denneler, B.; Berninger, F.; Tardif, J. Response of forest trees to increased atmospheric $\mathrm{CO}_{2}$. Crit. Rev. Plant Sci. 2007, 26, 265-283. [CrossRef]

15. Lévesque, M.; Siegwolf, R.; Saurer, M.; Eilmann, B.; Rigling, A. Increased water-use efficiency does not lead to enhanced tree growth under xeric and mesic conditions. New Phytol. 2014, 203, 94-109. [CrossRef] [PubMed]

16. Silva, L.C.R.; Anand, M. Probing for the influence of atmospheric $\mathrm{CO}_{2}$ and climate change on forest ecosystems across biomes. Glob. Ecol. Biogeogr. 2013, 22, 83-92. [CrossRef]

17. Peñuelas, J.; Canadell, J.G.; Ogaya, R. Increased water use efficiency during the 20th century did not translate into enhanced tree growth. Glob. Ecol. Biogeogr. 2011, 20, 597-608. [CrossRef] 
18. Wu, C.; Hember, R.A.; Chen, J.; Kurz, W.A.; Price, D.T.; Boisvenue, C.; Gonsamo, A.; Ju, W. Accelerating forest growth enhancement due to climate and atmospheric changes in British Colombia, Canada over 1956-2001. Sci. Rep. 2014, 4, 4461. [CrossRef]

19. Feng, X. Trends in intrinsic water-use efficiency of natural trees for the past 100-200 years: A response to atmospheric $\mathrm{CO}_{2}$ concentration. Geochim. Cosmochim. Acta 1999, 63, 1891-1903. [CrossRef]

20. Li, D.; Fang, K.; Li, Y.; Chen, D.; Liu, X.; Dong, Z.; Zhou, F.; Guo, G.; Shi, F.; Xu, C.; et al. Climate, intrinsic water-use efficiency and tree growth over the past 150 years in humid subtropical China. Glob. Planet. Chang. 2017, 148, 217-226. [CrossRef]

21. Huang, R.; Zhu, H.; Liu, X.; Liang, E.; Grießinger, J.; Wu, G.; Li, X.; Brauning, A. Does increasing intrinsic water use efficiency (iWUE) stimulate tree growth at natural alpine timberline on the southeastern Tibetan Plateau? Glob. Planet. Chang. 2017, 148, 217-226. [CrossRef]

22. Liu, X.; Wang, W.; Xu, G.; Zeng, X.; Wu, G.; Zhang, X.; Qin, D. Tree growth and intrinsic water-use efficiency of inland riparian forests in northwestern China: Evaluation via $\delta^{13} \mathrm{C}$ and $\delta^{18} \mathrm{O}$ analysis of tree rings. Tree Physiol. 2014, 34, 966-980. [CrossRef]

23. Xu, G.; Liu, X.; Qin, D.; Chen, T.; Wang, W.; Wu, G.; Sun, W.; An, W.; Zeng, X. Tree-ring $\delta^{18} \mathrm{O}$ evidence for the drought history of eastern Tianshan Mountains, northwest China since 1700 AD. Int. J. Climatol. 2013, 34, 3336-3347. [CrossRef]

24. Xu, G.; Liu, X.; Qin, D.; Chen, T.; Sun, W.; An, W.; Wang, W.; Wu, G.; Zeng, X.; Ren, J. Drought history inferred from tree ring $\delta^{13} \mathrm{C}$ and $\delta^{18} \mathrm{O}$ in the central Tianshan Mountains of China and linkage with the North Atlantic Oscillation. Theor. Appl. Climatol. 2014, 113, 385-401. [CrossRef]

25. Yu, S.; Yuan, Y.; Wei, W.; Chen, F.; Zhang, T.; Shang, H.; Zhang, R.; Qin, L. A 352-year record of summer temperature reconstruction in the western Tianshan Mountains, China, as deduced from tree-ring density. Quat. Res. 2013, 80, 158-166. [CrossRef]

26. Yuan, Y.; Jin, L.; Shao, X.; He, Q.; Li, Z.; Li, J. Variations of the spring precipitation day numbers reconstructed from tree rings in the Urumqi River drainage, Tianshan Mts. over the last 370 years. Chin. Sci. Bull. 2003, 48, 1507-1510. [CrossRef]

27. Yuan, Y.; Li, J.; Zhang, J. 348-year precipitation reconstruction from tree-rings for the North Slope of the middle Tianshan Mountains. Acta Meteorol. Sin. 2001, 15, 95-104.

28. Zhang, R.; Shang, H.; Yu, S.; He, Q.; Yuan, Y.; Bolatov, K.; Mambetov, B.T. Tree-ring-based precipitation reconstruction in southern Kazakhstan, reveals drought variability since A.D. 1770. Int. J. Climatol. 2017, 37, 741-750. [CrossRef]

29. Zhang, R.; Yuan, Y.; Gou, X.; He, Q.; Shang, H.; Zhang, T.; Chen, F.; Ermenbaev, B.; Yu, S.; Qin, L.; et al. Tree-ring-based moisture in western Tianshan Mountains since A.D. 1882 and its possible driving mechanism. Agric. For. Meteorol. 2016, 218-219, 267-276. [CrossRef]

30. Solomina, O.N.; Dolgova, E.A.; Maximova, O.E. Tree-ring based hydrometeorological reconstructions in Crimea, Caucasus and Tien-Shan. Nestor Hist. Mosc. St.-Petersbg. 2012, 232. (In Russian, with extended English summary).

31. Solomina, O.N.; Maximova, O.E.; Cook, E.R. Picea Schrenkiana ring width and density at the upper and lower tree limits in the Tien Shan mts Kyrgyz republic as a source of paleoclimatic information. Geogr. Environ. Sustain. 2014, 1, 66-79. [CrossRef]

32. Li, J.; Cook, E.; Chen, F.; Gou, X.; D'Arrigo, R.D.; Yuan, Y. An extreme drought event in the central Tien Shan area in the year 1945. J. Arid Environ. 2010, 74, 1225-1231. [CrossRef]

33. Li, J.; Gou, X.; Cook, E.R.; Chen, F. Tree-ring based drought reconstruction for the central Tien Shan area in northwest China. Geophys. Res. Lett. 2006, 33, L07715. [CrossRef]

34. Zhang, R.; Ermenbaev, B.; Zhang, T.; Ali, M.; Qin, L.; Satylkanov, R. The radial growth of schrenk spruce (Picea schrenkiana Fisch. et Mey.) records the hydroclimatic changes in the Chu River Basin over the past 175 Years. Forests 2019, 10, 223. [CrossRef]

35. Zhang, R.; Yuan, Y.; Yu, S.; Chen, F.; Zhang, T. Past changes of spring drought in the inner Tianshan Mountains, China, as recorded by tree rings. Boreas 2017, 46, 688-696. [CrossRef]

36. Zhang, R.; Qin, L.; Shang, H.; Yu, S.; Gou, X.; Mambetov, B.T.; Bolatov, K.; Zheng, W.; Ainur, U.; Bolatova, A. Climatic change in southern Kazakhstan since 1850 C.E. inferred from tree rings. Int. J. Biometeorol. 2020. [CrossRef] [PubMed] 
37. Zhang, R.; Wei, W.; Shang, H.; Yu, S.; Gou, X.; Qin, L.; Bolatov, K.; Mambetov, B.T. A tree ring-based record of annual mass balance changes for the TS.Tuyuksuyskiy Glacier and its linkages to climate change in the Tianshan Mountains. Quat. Sci. Rev. 2019, 205, 10-21. [CrossRef]

38. Zhang, R.; Zhang, T.; Kelgenbayev, N.; He, Q.; Mambetov, B.T.; Dosmanbetov, D.; Shang, H.; Yu, S.; Yuan, Y. A 189-year tree-ring record of drought for the Dzungarian Alatau, arid Central Asia. J. Asian Earth Sci. 2017, 148, 305-314. [CrossRef]

39. Wu, G.; Liu, X.; Chen, T.; Xu, G.; Wang, W.; Zeng, X.; Zhang, X. Elevation-dependent variations of tree growth and intrinsic water-use efficiency in Schrenk spruce (Picea schrenkiana) in the western Tianshan Mountains, China. Front. Plant Sci. 2015, 6, 309. [CrossRef] [PubMed]

40. Wu, G.; Liu, X.; Chen, T.; Xu, G.; Wang, W.; Zeng, X.; Wang, B.; Zhang, X. Long-term variation of tree growth and intrinsic water-use efficiency in Schrenk spruce with increasing $\mathrm{CO}_{2}$ concentration and climate warming in the western Tianshan Mountains, China. Acta Physiol. Plant. 2015, 37, 150. [CrossRef]

41. Speer, J.H. Fundamentals of Tree-ring Research; The University of Arizona Press: Tucson, AZ, USA, $2010 ;$; 333.

42. Holmes, R.L. Computer-assisted quality control in tree-ring dating and measurement. Tree Ring Bull. 1983, 43, 69-75.

43. Cook, E.R. A Time Series Analysis Approach to Tree Ring Standardization (Dendrochronology, Forestry, Dendroclimatology, Autoregressive Process); The University of Arizona: Tucson, AZ, USA, 1985; p. 185.

44. Cook, E.R.; Holmes, R.L. Users manual for program ARSTAN. In: Detecting dryness and wetness signals from tree-rings in Shenyang, Northeast China. Palaeogeogr. Palaeoecol. 1986, 302, 301-310.

45. Brendel, O.; Iannetta, P.P.M.; Stewart, D. A rapid and simple method to isolate pure alpha-cellulose. Phytochem. Anal. 2000, 11,7-10. [CrossRef]

46. Evans, M.N.; Schrag, D.P. A stable isotope-based approach to tropical dendroclimatology. Geochim. Cosmochim. Acta 2004, 68, 3295-3305. [CrossRef]

47. Coplen, T.B. Discontinuance of SMOW and PDB. Nature 1995, 375, 285. [CrossRef]

48. IAEA. Reference and intercomparison materials for stable isotopes of light elements. In Proceedings of the Consultants Meeting, TECDOC-825, International Atomic Energy Agency, Vienna, Austria, 1-3 December 1995.

49. Farquhar, G.D.; Ehleringer, J.R.; Hubick, K.T. Carbon isotope discrimination and photosynthesis. Annu. Rev. Plant Physiol. Plant Mol. Biol. 1989, 40,36. [CrossRef]

50. Ehleringer, J.R. Carbon and water relations in desert plants: An isotopic perspective. In Stable Isotopes and Plant Carbon- Water Relations; Saugier, B., Ehleringer, J.R., Hall, A., Eds.; Academic Press: San Diego, CA, USA, 1993; pp. 155-172.

51. Linares, J.C.; Camarero, J.J. From pattern to process: Linking intrinsic water-use efficiency to drought-induced forest decline. Glob. Chang. Biol. 2012, 18, 1000-1015. [CrossRef]

52. Shi, Y.; Shen, Y.; Kang, E.; Li, D.; Ding, Y.; Zhang, G.; Hu, R. Recent and future climate change in Northwest China. Clim. Chang. 2007, 80, 379-393. [CrossRef]

53. Campbell, G.S.; Norman, J.M. An Introduction to Environmental Biophysics, 2nd ed.; Springer: New York, NY, USA, 1998.

54. Zhang, R.; Yuan, Y.; Gou, X.; Zhang, T.; Zou, C.; Ji, C.; Fan, Z.; Qin, L.; Shang, H.; Li, X. Intra-annual radial growth of Schrenk spruce (Picea schrenkiana Fisch. et Mey) and its response to climate on the northern slopes of the Tianshan Mountains. Dendrochronologia 2016, 40, 36-42. [CrossRef]

55. McVicar, T.R.; Roderick, M.L.; Donohue, R.J.; Li, L.; Van Niel, T.G.; Thomas, A.; Grieser, J.; Jhajharia, D.; Himri, Y.; Mahowald, N.M.; et al. Global review and synthesis of trends in observed terrestrial near-surface wind speeds: Implications for evaporation. J. Hydrol. 2012, 416-417, 182-205. [CrossRef]

56. Eamus, D.; Boulain, N.; Cleverly, J.; Breshears, D.D. Global change type drought-induced tree mortality: Vapor pressure deficit is more important than temperature per se in causing decline in tree health. Ecol. Evol. 2013, 3, 2711-2729. [CrossRef]

57. Feng, $\mathrm{X}$. Long-term $C_{i} / C_{a}$ response of trees in western North America to atmospheric $\mathrm{CO}_{2}$ concentration derived from carbon isotope chronologies. Oecologia 1998, 117, 19-25. [CrossRef]

58. Ehleringer, J.R.; Cerling, T.E. Atmospheric CO2 and the ratio of intercellular to ambient $\mathrm{CO} 2$ concentrations in plants. Tree Physiol. 1995, 15, 105-111. [CrossRef]

59. Hietz, P.; Wanek, W.; Dunisch, O. Long-term trends in cellulose $13 \mathrm{C}$ and water-use efficiency of tropical Cedrela and Swietenia from Brazil. Tree Physiol. 2005, 25, 745-752. [CrossRef] [PubMed] 
60. Giguere-Croteau, C.; Boucher, E.; Bergeron, Y.; Girardin, M.P.; Drobyshev, I.; Silv, L.C.R.; Helie, J.F.; Garneau, M. North America's oldest boreal trees are more efficient water users due to increased [CO2], but do not grow faster. Proc. Natl. Acad. Sci. USA 2019, 116, 2749-2754. [CrossRef] [PubMed]

61. Chen, Z.; Zhang, X.; He, X.; Davi, N.K.; Li, L.; Bai, X. Response of radial growth to warming and CO2 enrichment in southern Northeast China: A case of Pinus tabulaeformis. Clim. Chang. 2015, 130, 559-571. [CrossRef]

62. Zhang, X.; Liu, X.; Zhang, Q.; Zeng, X.; Xu, G.; Wu, G.; Wang, W. Species-specific tree growth and intrinsic water-use efficiency of Dahurian larch (Larix gmelinii) and Mongolian pine (Pinus sylvestris var. mongolica) growing in a boreal permafrost region of the Greater Hinggan Mountains, Northeastern China. Agric. For. Meteorol. 2018, 248, 145-155. [CrossRef]

63. Tezara, W.; Mitchell, V.J.; Driscoll, S.D.; Lawlor, D.W. Water stress inhibits plant photosynthesis by decreasing coupling factor and ATP. Nature 1999, 401, 914-917. [CrossRef]

(C) 2020 by the authors. Licensee MDPI, Basel, Switzerland. This article is an open access article distributed under the terms and conditions of the Creative Commons Attribution (CC BY) license (http://creativecommons.org/licenses/by/4.0/). 